\title{
SPATIAL DISTRIBUTION OF SKIN AND MUSCLE METACERCARIAE (DIGENEA) OF ROACH, RUTILUS RUTILUS, AND BLEAK, ALBURNUS ALBURNUS (ACTINOPTERYGII: CYPRINIFORMES: CYPRINIDAE), FROM AN ESTUARY LAKE IN CENTRAL EUROPE
}

\author{
Karolina OSTROWSKA ${ }^{1}$, Gerard WIŚNIEWSKI ${ }^{2}$, and Wojciech PIASECKI ${ }^{3}$ \\ ${ }^{1}$ Egis Polska, Warszawa, Poland \\ ${ }^{2}$ Pomorska Organizacja Producentów ARKA, Gdynia, Poland \\ ${ }^{3}$ Institute of Marine and environmental Sciences, University of Szczecin, Poland
}

\begin{abstract}
Ostrowska K., Wiśniewski G., Piasecki W. 2019. Spatial distribution of skin and muscle metacercariae (Digenea) of roach, Rutilus rutilus, and bleak, Alburnus alburnus (Actinopterygii: Cypriniformes: Cyprinidae), from an estuary lake in central Europe. Acta Ichthyol. Piscat. 49 (4): 421-429.
\end{abstract}

\begin{abstract}
Adult stages of digenean flukes are usually well studied, but their larval forms, the metacercariae, do not receive comparable attention of researchers. As a consequence, metacercariae, especially small ones, are routinely overlooked, despite their serious epidemiological and epizootic potential. Therefore, the existing distribution data are patchy and the biogeographic knowledge is far from being complete. We were not able to trace any papers focusing on the depth of penetration of digenean metacercariae in fish tissues. There have been almost no surveys on the metacercariae density (ind. $\cdot \mathrm{g}^{-1}$ ) in fish muscles. In this study, we were trying to determine the spatial distribution of metacercariae in the muscles of two freshwater cyprinid fishes, the roach, Rutilus rutilus (Linnaeus, 1758) and the bleak, Alburnus alburnus (Linnaeus, 1758). The study area was Lake Dąbie, a large and shallow deltaic lake of the Oder (Odra) River estuary, Poland. We studied a total of 40 roach (12.0-21.5 cm TL 30-120 g TW) and 15 bleak (10.5-14.5 cm TL). The fishes were filleted and each filet was divided into four parts. All muscle tissues were examined for the presence of metacercariae using a trichinoscope and a dissecting microscope. Dorsal muscles of an additional 12 roach were sliced and the depth of metacercariae penetration was assessed. The dominant muscle parasite was Paracoenogonimus ovatus. Metacercariae of other species (Posthodiplostomum cuticula and Apophallus muehlingi) were only sporadically found in muscles roach and bleak (with a preference to the shin). The prevalence of $P$. ovatus in roach ranged from $66.7 \%$ to $100 \%$ and the highest infection intensity was 1973 specimens in one fish. The majority of metacercariae (354 out of 363) were found in the outer $50 \%$ of the muscle depth. The infection parameters differed between length classes of roach with the class $14.0-15.9$ being infected in 100\%. The presently reported finding of Paracoenogonimus ovatus in bleak, Alburnus alburnus, constitutes a new hosts record.
\end{abstract}

Keywords: metacercariae, fish, muscle, spatial distribution, parasite, infection, new host record

\section{INTRODUCTION}

Freshwater fishes are commonly infected with parasites representing different taxonomic groups, including digenean flukes (Trematoda: Digenea) for which fishes are either final hosts or second intermediate hosts. Adult stages of digeneans are usually well studied, but their larval forms, the metacercariae, do not receive comparable attention of researchers. The majority of parasitological surveys of fishes, especially helminthological studies, target intestinal parasites only. As a consequence, metacercariae, especially small ones, are routinely overlooked, despite their serious epidemiologic and epizootic potential. Therefore, the existing distribution data are patchy and the biogeographic knowledge is not yet complete. We were not able to trace any papers focusing on the depth of penetration of digenean metacercariae in fish tissues. In this study, we were trying to fill this gap in the knowledge.

One of the most prevalent fish parasites in central and eastern Europe is Paracoenogonimus ovatus Katsurada, 1914, known to cause serious pathological changes in common bream (Wierzbicka and Einszporn-Orecka 1972). In fishes, it is found as a metacercaria located on the skin and in the muscles. As a digenean representing the family Cyathocotylidae, it has a complex life cycle involving a snail and a fish, as the first and the second

* Correspondence: Prof. dr hab. Wojciech Piasecki, Instytut Nauk o Morzu i Środowisku, Uniwersytet Szczeciński, ul. Mickiewicza 16, 70-383 Szczecin, Poland, phone: +48-91-444-2483, e-mail: (WP) wojciech.piasecki@usz.edu.pl, (KO) karolina.ostrowska@egis.pl, (GW) gerard.wisniewski@o2.pl; ORCID: (WP) 0000-0003-2536-7813. 
intermediate host, respectively (Komiya 1938, Kozicka and Niewiadomska 1958, Besprozvannykh and Ermolenko 2009). The final hosts are piscivorous birds (Rząd et al 2013). According to Sulgostowska (2007), who studied aquatic bird parasites, $P$. ovatus was one of the dominant parasite species in the biocoenosis of the Masurian lakes (NE Poland). The first intermediate host of this digenean are snails, Viviparus viviparus (see Jeżewski 2004) and Contectiana contecta (see Zhytova et al 2019). In Poland, at least 13 species of freshwater fish species, such as crucian carp, Carassius carassius (Linnaeus, 1758); barbel, Barbus barbus (Linnaeus, 1758); common bream, Abramis brama (Linnaeus, 1758); blue bream, Ballerus ballerus (Linnaeus, 1758); white bream, Blicca bjoerkna (Linnaeus, 1758); common dace, Leuciscus leuciscus (Linnaeus, 1758); ide, Leuciscus idus (Linnaeus, 1758); common roach, Rutilus rutilus (Linnaeus, 1758); rudd, Scardinius erythrophthalmus (Linnaeus, 1758); European perch, Perca fluviatilis Linnaeus, 1758; ruffe, Gymnocephalus cernua (Linnaeus, 1758); northern pike, Esox lucius Linnaeus, 1758; and tench Tinca tinca (Linnaeus, 1758) have hitherto been reported as the second intermediate hosts of this parasite (Grabda 1971, Sobecka et al. 2004, Linowska and Sobecka 2015, Woliński and Piasecki unpublished*). Paracoenogonimus ovatus has also been reported from common bream in Latvia (Zolovs et al. 2018), from western tubenose goby, Barbatula barbatula (Linnaeus, 1758), in Russia (Zhokhov et al. 2017), from stone loach, Cobitis taenia Linnaeus, 1758, in Russia (Mineeva 2016, Shershnevaa and Zhokhov 2013); from common roach, white bream, common bream, rudd, northern pike, Prussian carp, Carassius gibelio (Bloch, 1782), and pike-perch, Sander lucioperca (Linnaeus, 1758) in Mykolaiv region, Ukraine (Goncharov and Soroka 2015). Ieshko et al. (2001) found P. ovatus on the heart of grayling, Thymallus thymallus (Linnaeus, 1758), in northern Norway. Additional Russian records of $P$. ovatus from Russia were listed by Zhokhov et al. (2017) who studied parasites in the Rybinsk Reservoir, but unfortunately, some of the listed references are from poorly accessible sources.

Human infections by trematodes representing digenean families Opisthorchiidae and Heterophyidae are well documented (Schuster et al. 1998, Hong 2000, Nawa et al. 2005, Sobecka and Piasecki 2011) but the family Cyathocotylidae, represented in this paper by $P$. ovatus, has been rarely blamed for infecting mammals. Among notable exceptions are articles by Chandler (1950) and El-Assal et al. (1986) who documented cyathocotylid infections of dogs and cats.

The existing records of $P$. ovatus in European fishes are usually parts of larger surveys, rarely focusing on the spatial distribution within the fish body or the infection seasonality. Nobody has hitherto attempted to determine how deep those parasites penetrate the fish muscles. Therefore, the presently reported study was intended to study also the spatial distribution of the metacercariae in the muscles of two cyprinid fishes, the common roach
Rutilus rutilus and bleak, Alburnus alburnus (Linnaeus, 1758). There have been no comprehensive surveys on the metacercariae density (ind. $\mathrm{g}^{-1}$ ) in fish muscles.

\section{MATERIAL AND METHODS}

Common roach. A sample consisting of 40 roach, Rutilus rutilus, was taken from Lake Dąbie (Szczecin, Poland) on 23 November 1998. The fish were acquired from commercial fishermen representing two fishing ports, Skolwin and Dąbie, belonging to the cooperative "Certa". The total length of roach studied ranged from 12 to 21.5 $\mathrm{cm}$, while their weight was within 30-120 g. The fish were filleted, skinned, and examined in detail under dissecting microscope after squashing between two glass plates of a trichinoscope (each quarter of a filet separately). The parasites found were identified and counted. Skin and fins were examined macroscopically for black-spot fluke larvae. An additional sample of 12 fish was taken on 12 April 1999 to determine how deep in the muscles the metacercariae were located. The fish were cut into thin slices and relative depth of the cysts was noted and marked on a diagram. For practical reasons, only the dorsal muscles were examined.

Common bleak. A sample consisting of 15 bleak, Alburnus alburnus (10.5-14.5 cm TL), was collected on fish and rod, by one of the authors (GW) on 12 May 1999. The fish after transferring to the laboratory we subjected to the same procedures as $R$. rutilus, with the exception for determining the depth of location of the metacercariae in the muscles.

Study area. Lake Dąbie, situated in the NW Poland is the fourth largest lake of this country and it is a flow-through body of water in the Oder River estuary. Its entire area lies within the city limits of Szczecin ${ }^{* *}$. The lake, which is $15 \mathrm{~km}$ long and, $7.5 \mathrm{~km}$ wide is rather shallow $(2.6 \mathrm{~m})$ (Wiśniewski and Wolski 2005).

The fishes were examined following commonly accepted parasitological methods. Infection parameters were determined following Bush et al. (1997).

\section{RESULTS}

Common roach. The skin, fins, and the muscles of roach, Rutilus rutilus, were parasitized by metacercariae of three species of digenean flukes, namely Posthodiplostomum cuticola (von Nordmann, 1832) Dubois, 1936; Apophallus muehlingi (Jägerskiöld, 1899) Lühe, 1909; and Paracoenogonimus ovatus Katsurada, 1914. The former species (Fig. 1A) occurred on the skin and fins only, affecting $27.5 \%$ of the host fish and the intensity ranged from 1 to 6 specimens. The prevalence of $A$. muehlingi (Fig. 1B) was $10 \%$, while the intensity was $1-3$ ind. This parasite occurred not only on the skin and fins but also occasionally in the muscles. Encysted metacercariae of Posthodiplostomum cuticola and A. muehlingi were well marked by dark pigment surrounding them.

The third species-Paracoenogonimus ovatus (Fig. 1C) was predominantly a muscle parasite, very abundant and prevalent. It had a delicate double-layer cyst wall and

\footnotetext{
Woliński J., Piasecki W. Katalog fauny pasożytniczej Polski. Catalogus faunae parasiticae poloniae. Część II. Pasożyty krągłoustych i ryb. Parasiti cyclostomatorum et piscium. [Catalogue of Polish parasite fauna. Part II. Parasites of cyclostomes and fishes.] (Suplement 1970-1996). [In Polish.]

https://www.google.com/maps/place/Szczecin
} 
its presence was not associated with external pigmentation. We documented also a shape of a metacercaria liberated from the cyst (Fig. 1D). Occasionally we encountered metacercariae that we were not able to identify. We also


observed some metacercariae that were desiccated and shrunk (Fig. 1E). What is important were able to document some metacercaria in lateral view showing that they were folded (Fig. 1F)
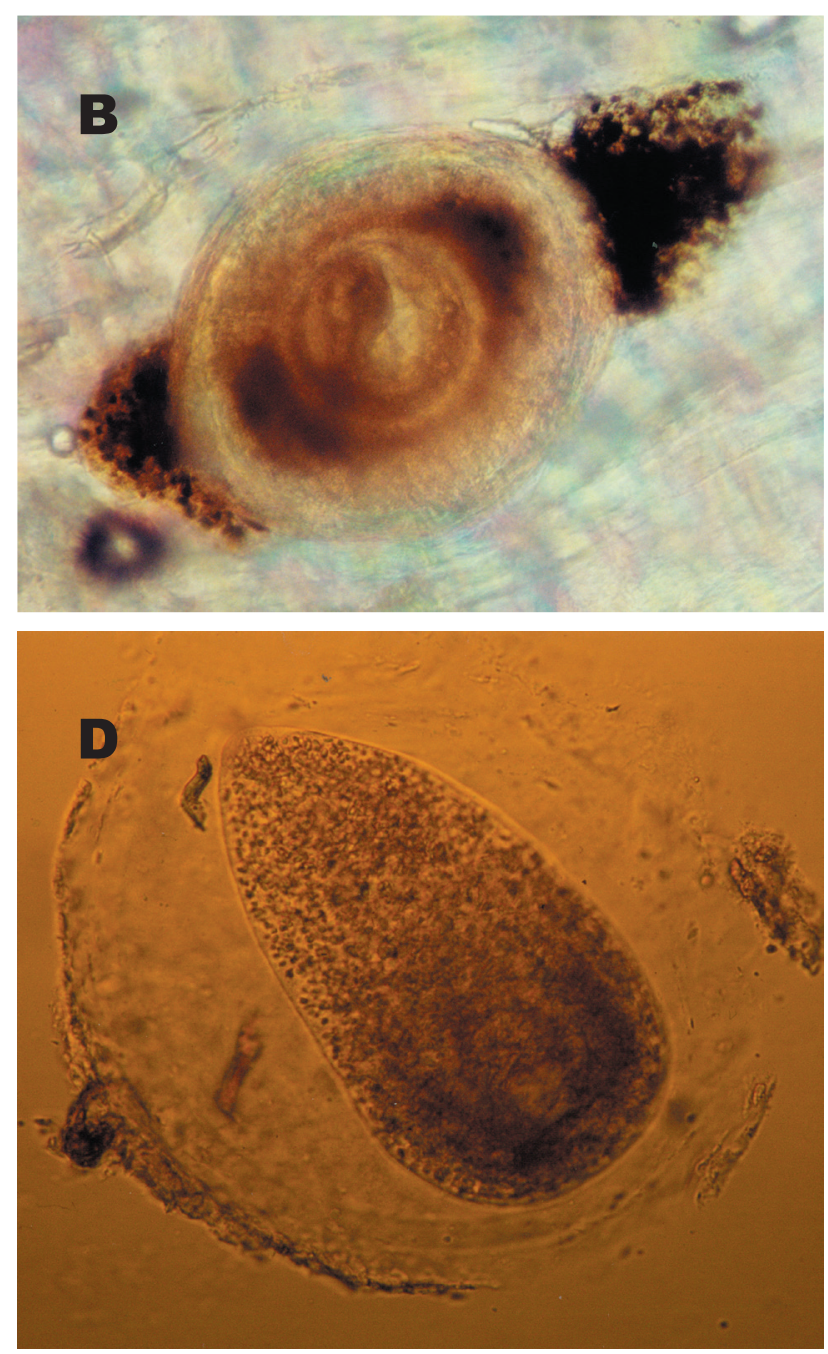

Fig. 1. Metacercariae found on the skin and in the muscles of roach, Rutilus rutilus (B, C, F), and bleak, Alburnus alburnus (A, D, E) from Lake Dąbie, Poland; Posthodiplostomum cuticola (skin only) (A), Apophallus muehlingi (B), Paracoenogonimus ovatus $(\mathbf{C}, \mathbf{D}, \mathbf{E}, \mathbf{F})$; desiccated specimen $(\mathbf{E})$; dark specimen; photo: K. Ostrowska $(\mathrm{B}, \mathrm{C}, \mathrm{F})$ and G. Wiśniewski (A, D, E) 
The overall prevalence of the infection with Paracoenogonimus ovatus was $90 \%$ and the intensities were generally very high reaching as many as 1973 metacercariae in a single fish (Table 1). The latter intensity translated into a density of 66 parasites per $1 \mathrm{~g}$ of muscles. The mean intensity of infection was 455.2, while the abundance-409.7 parasites per fish. Jointly, a total of $1042 \mathrm{~g}$ of the muscles studied, yielded a total of 16388 metacercariae. The mean density of infection was 15.7 ind. $\cdot \mathrm{g}^{-1}$.

The infection parameters differed among the length classes of the roach. The highest prevalence of $100 \%$ showed the fish of length class $14.0-15.9 \mathrm{~cm}$ while the lowest (66.7\%) - the class 20.0-21.9 cm (Fig. 2). The highest intensity of infection (1973) pertained to the class of 18.0-19.9 cm, while the lowest (77) - to the class of 20.0-21.9 cm. The highest mean intensity and abundance (698 ind. per fish and 634.5 ind. per fish, respectively) were noted for the class of $16.0-17.9 \mathrm{~cm}$. The highest density of 29.7 ind. $\cdot \mathrm{g}^{-1}$ was observed in the fish of class 14.0-15.9 cm (Fig. 3). The lowest values of the mean intensity, abundance, and density were in class 20-21.9 cm (44.0, 29.3, and 0.6, respectively).

The mean density of the right-side fillet was 14.5 ind. $\mathrm{g}^{-1}$ while that of the left-side fillet-17.0 ind. $\cdot \mathrm{g}^{-1}$ (Fig. 3 ). The highest density was observed in quarter No. 1 of the left side -28.9 ind. $\cdot \mathrm{g}^{-1}$, while the lowest $\left(8.0\right.$ ind. $\left.\cdot \mathrm{g}^{-1}\right)$ in right-side quarter No. 3 (Fig. 4). The dorsal quarters harboured jointly 9181 metacercariae, while the ventral ones - a total of 7207 .

Metacercariae of Paracoenogonimus ovatus in roach tended to concentrate in subcutaneous layers of the muscles. The majority of specimens were found at relative depths of $0-50 \%$ (Fig. 5). Out of 363 metacercariae observed in the thin sections of the body as many as 354 were located in the latter range. Moreover, the preferred sectors were the most dorsal ones (Fig. 5). Metacercariae of P. ovatus found in the muscles of roach, even in the specimen with the highest density of infection (66 parasites per $1 \mathrm{~g}$ of muscles), did not cause apparent pathological changes.

Bleak. All except one bleak, Alburnus alburnus, were parasitized by metacercariae of either Posthodiplostomum cuticola and/or Paracoenogonimus ovatus. Five fish were infected by both parasites, while $46.7 \%$ of bleak had only Paracoenogonimus ovatus and $13.3 \%$ of fish was infected by Posthodiplostomum cuticola. The intensity of infection of P. ovatus in fish of the length class 13.5-14.5 ranged from 21 to 34 metacercariae while smaller bleak had only 2-9 parasites. The majority of $P$. ovatus $43.4 \%$ ) was found in muscle sectors 2 , further $21.4 \%$ and $20.9 \%$ were found in sectors 4 and 4, respectively. The least infected parts of the body were sectors No. 1 with 14.3\% metacercariae (Fig. 6A).

The infection parameters of bleak with skin metacercariae of Posthodiplostomum cuticola was low (Fig. 6B).

\section{DISCUSSION}

The presently reported study was inspired by three papers. The first one by Schuster et al. (1998) indicated that in the nearby State of Brandenburg (Germany) a number of different species of digenean metacercariae
Table 1

Infection parameters of metacercariae of three digenean species found in the skin and muscles of roach, Rutilus rutilus, from Lake Dąbie, Poland

\begin{tabular}{|c|c|c|c|c|c|c|}
\hline Parasite species & $\begin{array}{l}\overline{0} \\
\frac{0}{0} \\
\frac{0}{0} \\
\frac{0}{0} \\
0 \\
0\end{array}$ & 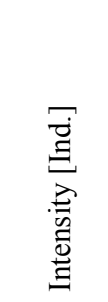 & 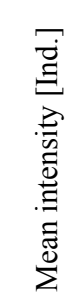 & 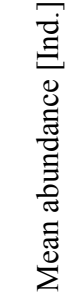 & $n$ & $N$ \\
\hline $\begin{array}{l}\text { Paracoenogonimus } \\
\text { ovatus }\end{array}$ & 90.0 & $1-1973$ & 455.2 & 409.7 & 16300 & 36 \\
\hline $\begin{array}{l}\text { Posthodiplostomum } \\
\text { cuticola }\end{array}$ & 27.5 & $1-6$ & 2.3 & 0.6 & 25 & 11 \\
\hline Apophallus muehlingi & 10.0 & $1-3$ & 1.5 & 0.2 & 6 & 4 \\
\hline
\end{tabular}

$n=$ total number of parasites found, $N=$ Number of fish specimens infected.

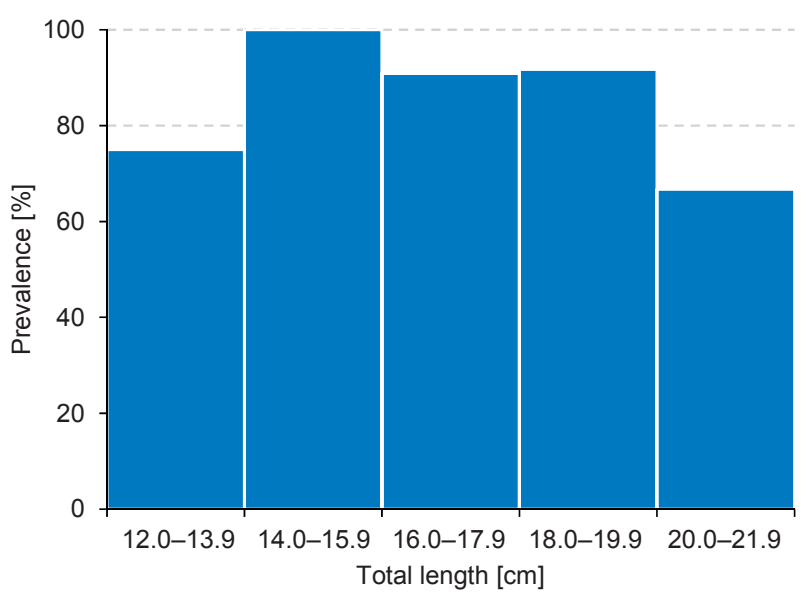

Fig. 2. Prevalence of infection with metacercariae of Paracoenogonimus ovatus in the muscles of roach, Rutilus rutilus, from Lake Dąbie, Poland in length classes (TL)

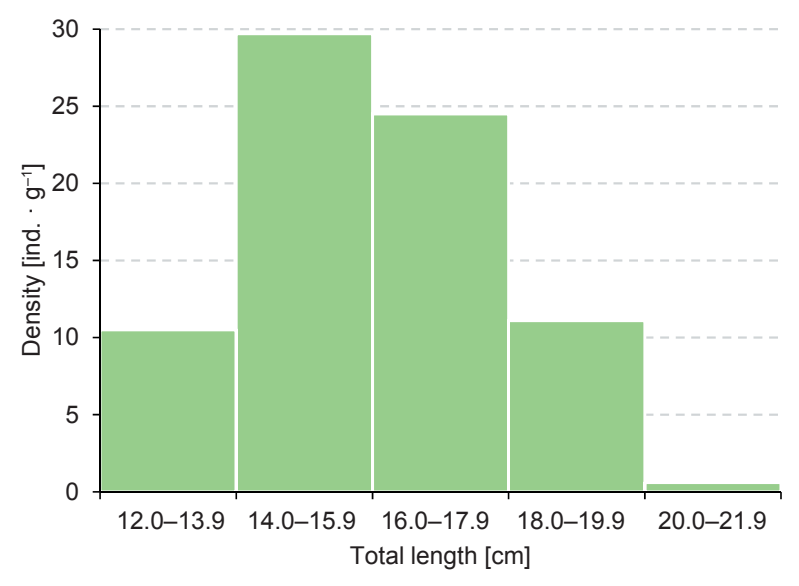

Fig. 3. Density of infection with metacercariae of Paracoenogonimus ovatus in the muscles of roach, Rutilus rutilus, from Lake Dąbie, Poland in length classes (TL) 

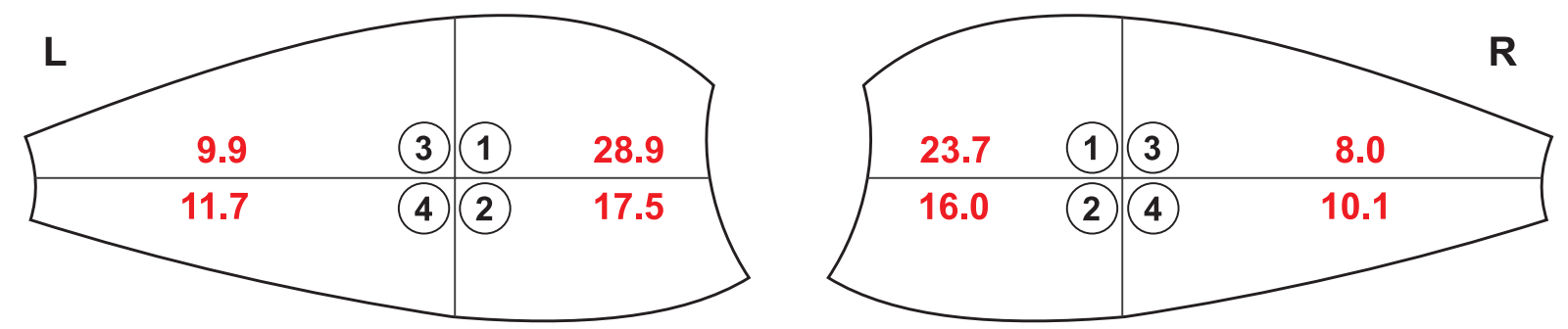

Fig. 4. The density of Paracoenogonimus ovatus metacercariae in individual quarters of both fillets of roach, Rutilus rutilus, from Lake Dąbie, Poland

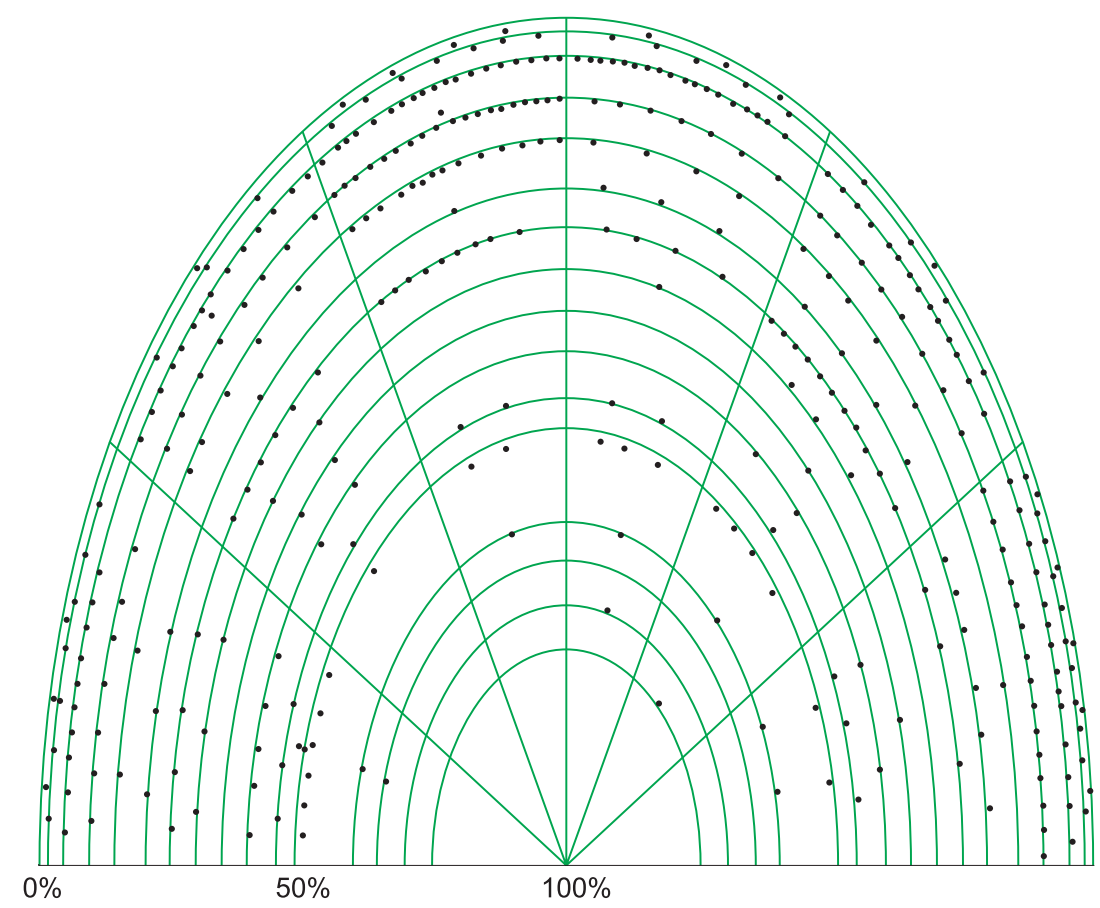

Fig. 5. Diagrammatic distribution of Paracoenogonimus ovatus metacercariae at different depths (expressed as percentage) in the dorsal muscles of roach, Rutilus rutilus, from Lake Dąbie, Poland

had been discovered in the muscles of cyprinid fishes and in the alimentary tract of foxes and cats. Secondly, Wierzbicka and Einszporn-Orecka (1972) reported cases of emaciated common bream from the nearby Lake Dąbie, caused by Paracoenogonimus ovatus. Thirdly, Bortnowska (unpublished*), suggested a growing interest of food-science in freshwater fishes as a raw-material for sashimi-like products involving usage of raw fish meat (This growing interest was later indicated by numerous publications, e.g., Nawa et al. 2005). All three signals combined prompted the present authors to determine how safe for consumption would be roach and bleak from a local lake in the aspect of being parasitized by larval stages of Digenea.

The principal parasite species found in roach and bleak was $P$. ovatus, representing a digenean family Cyathocotylidae, potentially pathogenic for humans. Two other species, Posthodiplostomum cuticola and Apophallus muehlingi, usually associated with the black- spot disease of fish, were much less prevalent. The former represents the family Diplostomidae, while the latter the Heterophyidae, well known as bird and mammal parasites.

The genus Paracoenogonimus Katsurada, 1914 was revised by Dubois (1983). He recognised only two valid species in this genus, namely Paracoenogonimus ovatus Katsurada, 1914 and Paracoenogonimus szidati(Anderson, 1944). Recently the third species Paracoenogonimus ussurensis Besprozvannykh et Ermolenko, 2009 was described from fish of Far East Russia (Besprozvannykh and Ermolenko 2009) and subsequently reported by another researcher from the same area (Sokolov 2013).

Paracoenogonimus ovatus was described by in 2014 Katsurada based on the stage of metacercaria from cyprinid fishes from the Elbe and Alster rivers in Germany (Dubois 1983) and this seems to be the westernmost record of this parasite. In Poland, at least 13 species of freshwater fish species, such as crucian carp, barbel, common bream, blue bream, white bream, common dace, ide, common roach, 

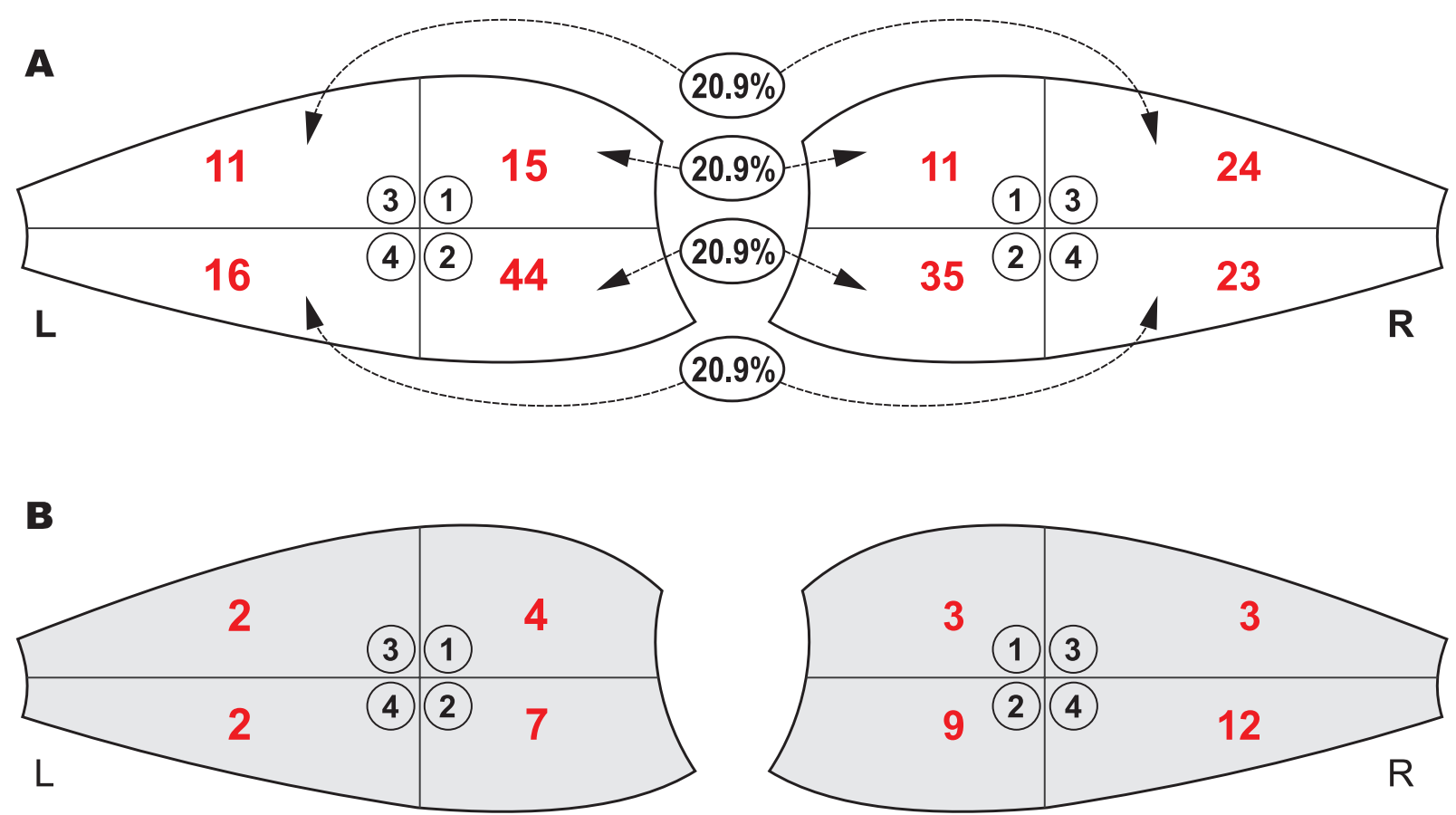

Fig. 6. The total number of metacercariae in individual quarters of muscles of roach, Rutilus rutilus (A), and skin of bleak, Alburnus alburnus (B), from Lake Dąbie, Poland; (A) Paracoenogonimus ovatus; and (B) Posthodiplostomum cuticola; L and R represent the left and right filets, respectively

rudd, European perch, ruffe, northern pike, and tench have hitherto been reported as the second intermediate hosts of this parasite (Grabda 1971, Sobecka et al. 2004, Linowska and Sobecka 2015, Woliński and Piasecki unpublished*). The parasite was also found in southern Ukraine by Goncharov and Soroka (2015) which is the southernmost record. The Latvian finding of $P$. ovatus (see Zolovs et al. 2018 ) is probably the northernmost record of this species. (The finding of $P$. ovatus from the heart of grayling, Thymallus thymallus, in northern Norway by Ieshko et al. 2001 seems quite unusual.) Russian records are associated with the drainage basin of the Volga River and they reach as far east as the Saratov Reservoir (Mineeva 2016). Goncharov and Soroka (2015), citing other authors, stated that $P$. ovatus was found in Russia, Poland, Germany, the Netherlands, Romania, Hungary, Finland, Latvia, Norway, Azerbaijan, Czech Republic, Slovakia, and Belarus. The presently reported finding of $P$. ovatus in bleak, constitutes a new host record.

According to Ginetsinskaya (cited by Goncharov and Soroka 2015) the larval migration process, following the invasions by the cercariae, in the fish tissues is "accompanied by multiple haemorrhages, which likely caused rapid (within a few hours) death of infected fry". The cercarial invasions are probably seasonal, therefore we were not able to see any apparent pathology associated with the presence of metacercariae. Even the highest density of infection by metacercariae of Paracoenogonimus ovatus, reaching 66 ind. $\cdot \mathrm{g}^{-1}$, did not cause visible pathological changes. Strong emaciation was observed by Wierzbicka and Einszporn-Orecka (1972) in common bream, where the density reached 95 ind. $\cdot \mathrm{g}^{-1}$. Such condition of skinny big bream has been known to local fishermen, who dubbed such specimens "deska" (board, plate).

According to Ginetsinskaya the metacercariae are fully encysted after 30 days. We were able to observe that the metacercarial capsule was composed of two layers, A thin inner one and the thick outer one. The encapsulation process of digenean metacercariae was studied by (Skorobrekhova 2009). She determined that the inner capsule was probably formed by the parasite while that outer one by the host. As a consequence, at some point, the parasite becomes isolated from the host and its energy sources are limited. Therefore, we assume that after a certain period of time metacercariae die out, desiccate, and shrink (Fig. 1E). The best visible elements of the encysted larva are its excretory canals filled with excretory granules that refract the light (Fig 1C). Some metacercariae observed by us much stronger refracted light so they were quite dark (Fig. 1F).

The metacercarial cyst of $P$. ovatus is regularly spherical, approximately $0.45 \mathrm{~mm}$ in diameter. Metacercariae liberated from their cysts are substantially longer, reaching almost $0.6 \mathrm{~mm}$. Available diagrammatic visualisations of Paracoenogonimus metacercariae found in the literature (Wierzbicka and Einszporn-Orecka 1972, Besprozvannykh and Ermolenko 2009) suggest that the larva is squeezed along its longer axis (Fig. 7A). We observed that they are folded inside the cyst (Figs. 1F, 7B), which helps them to optimise the spherical space they have for their disposal.

The presently reported infection parameters $P$. ovatus are very high, particularly in roach. This is consistent with Goncharov and Soroka 2015 and in general consistent 

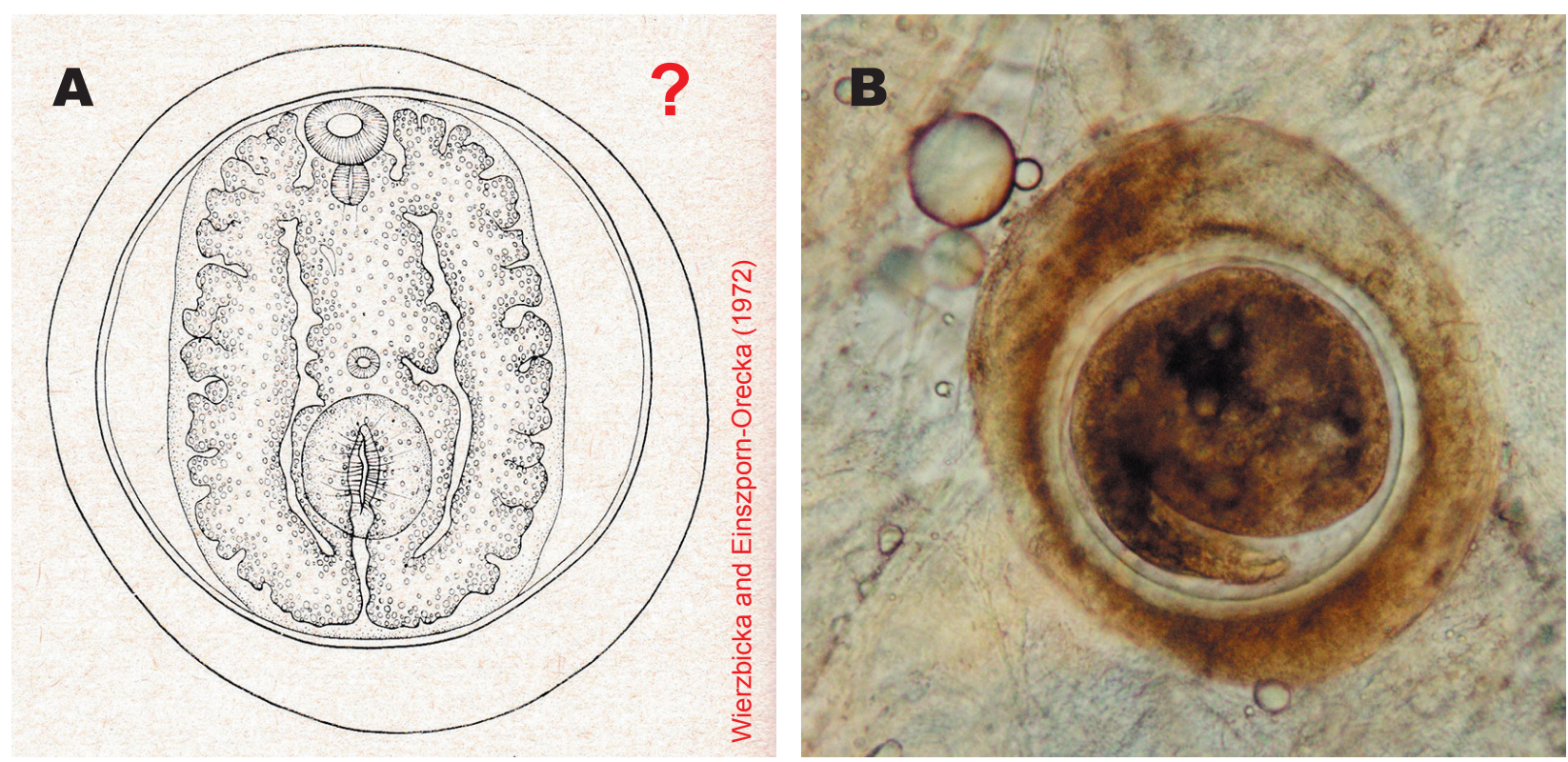

Fig. 7. Metacercaria of Paracoenogonimus ovatus (ventral view) from the muscles of common bream, Abramis brama, illustrated by Wierzbicka and Einszporn-Orecka (1972) (A) and the same species (lateral view) from roach, Rutilus rutilus, (B) from Lake Dąbie, Poland (photograph by K. Ostrowska)

with very high prevalence, intensity and density values observed for cyprinid fishes (Grabda 1971, Sobecka et al. 2004, Woliński and Piasecki unpublished*). Our observations confirm the statement of (Sulgostowska 2007) that $P$. ovatus may one of the dominant parasite species in the biocoenosis, in this case, the biocoenosis of Lake Dąbie. The presently observed infection parameters of bleak were rather low.

The observed distribution of $P$. ovatus metacercariae probably reflects a higher vulnerability of certain body parts for active penetration. It may be related to the differences in the hydrodynamic pressure on the surface of a swimming fish or with the density of the sensory cells on the skin. The presented results of the depth of penetration and, in some cases, the massive scale of this phenomenon, may further confirm the assumption that $P$. ovatus is potentially lethal for a fish fry.

Paracoenogonimus ovatus is not very host specific at the stage of metacercaria. Those parasites are most commonly found in fishes of the family Cyprinidae and less frequently in those representing Percidae, Esocidae, Gobiidae etc. (Grabda 1971, Besprozvannykh and Ermolenko 2009, Goncharov and Soroka 2015, Woliński and Piasecki unpublished*). It is, therefore, possible that the parasite is capable of developing in the majority of freshwater fishes.

In Poland, Paracoenogonimus ovatus, was recorded from piscivorous birds, such as red-throated loon, Gavia stellata (see Okulewicz 1984), common buzzard, Buteo buteo (see Sulgostowska and Czaplińska 1987), common merganser, Mergus merganser and western marsh harrier, Circus aeruginosus (see Sulgostowska 2007), white-tailed eagle, Haliaeetus albicilla (see Kalisińska et al 2008), tufted duck, Aythya fuligula, and greater scaup, Aythya marila (see Rząd et al. 2013). All of the above mentioned species may potentially occur in Lake Dąbie. Moreover, also adult $P$. ovatus is not host specific. Seo et al. (2008) were able to experimentally infect chicken. Chandler (1950) El-Assal et al. (1986) documented infections of dogs and cats by related species of flukes (family Cyathocotylidae). Katsurada (cited by Goncharov and Soroka 2015) we able to experimentally infect mice with $P$. ovatus. The fact of mass infection of muscles of cyprinid fishes by metacercariae has not been widely publicized, which in conjunction of the growing interest in oriental cuisine, and especially attempts of utilizing local freshwater fish for sashimi like dishes constitutes a potential threat to human health. We were not able to identify some metacercariae, which means that among them might be also renown human parasites such as the cat fluke, Opisthorchis felineus (Rivolta, 1884) Blanchard, 1895. It is therefore suggested that centralEuropean freshwater cyprinid fishes should not be eaten raw or used for sashimi-like products. Sanitary authorities should be alerted about this epidemiological threat.

\section{REFERENCES}

Besprozvannykh V.V., Ermolenko A.V. 2009. Life-cycle of Paracoenogonimus ussuriensis sp. n. (Digenea: Cyathocotylidae) in the Primorsky region (southern Far East, Russia) Helminthologia 46 (2): 100-106. DOI: $10.2478 /$ s1 1687-009-0020-0

Bush A.O., Lafferty K.D., Lotz J.M., Shostak A.W. 1997. Parasitology meets ecology on its own terms: Margolis et al. revisited. Journal of Parasitology 83 (4): 575-583. DOI: 10.2307/3284227

Chandler A.C. 1950. Mesostephanus longisaccus, a new cyathocotylid trematode from a dog. Journal of Parasitology 36 (1): 90. DOI: 10.2307/3273509 
Dubois G. 1983. Les trématodes des genres Prohemistomum Odhner, 1913 et Paracoenogonimus Katsurada, 1914 (Strigeata: Cyathocotyloidea). Annales de parasitologie humaine et comparée 58 (6): 549-556. DOI: 10.1051/parasite/1983586549

El-Assal F.M., Tawfik M.A.A., El Aroussi N. 1986. Three Egyptian trematodes of fish-eating mammals of family Cyathocotylidae (Poche, 1926). Zeitschrift fur Parasitenkunde 72 (1): 73-82. DOI: 10.1007/BF00927736

Goncharov S.L., Soroka N.M. 2015. The occurrence of Paracoenogonimus ovatus (Trematoda, Cyathocotylidae) in fish of natural reservoirs of Mykolaiv region. Vestnik Zoologii 49 (5): 421-426. DOI: 10.1515/vZoo-2015-0048

Grabda J. 1971. Katalog fauny pasożytniczej Polski. Catalogus faunae parasiticae poloniae. Część II. Pasożyty krągłoustych i ryb. Parasiti cyclostomatorum et piscium. [Catalogue of Polish parasite fauna. Part II. Parasites of cyclostomes and fishes.] PWN, Warszawa - Wrocław, Poland. [In Polish.]

Hong S.-J. 2000. A human case of Stellantchasmus falcatus infection in Korea. Korean Journal of Parasitology 38 (1): 25-27. DOI: $10.3347 / \mathrm{kjp} .2000 .38 .1 .25$

Ieshko E.P., Johnsen B.O., Shulman B.S., Jensen A.J., Schurov I.L. 2001. The parasite fauna of an isolated population of grayling, Thymallus thymallus (L.) in the river Vefsna, northern Norway. Bulletin of the Scandinavian Society for Parasitology 11 (1-2): 37-41.

Jeżewski W. 2004. Occurrence of Digenea (Trematoda) in two Viviparus species from lakes, rivers and a dam reservoir. Helminthologia 41 (3): 147-150.

Kalisińska E., Rząd I., Sitko J., Kavetska K.M., Królaczyk K., Budis H. 2008. Digenea Haliaeetus albicilla (Linnaeus, 1758) i Pandion haliaetus (Linnaeus, 1758) ze środkowej i północno-zachodniej Polski. [Digenea of Haliaeetus albicilla (Linnaeus, 1758) and Pandion haliaetus (Linnaeus, 1758) from middle and north-western Poland. Wiadomości Parazytologiczne 54 (4): 349-351. [In Polish.]

Komiya Y. 1938. Die Entwicklung des Exkretionssystems einiger Trematodenlarven aus Alster und Elbe, nebst Bemerkungen über ihren Entwicklungszyklus. Zeitschrift für Parasitenkunde 10 (3): 340-385. DOI: 10.1007/BF02123446

Kozicka J., Niewiadomska K. 1958. Life cycle of Paracoenogonimus viviparae (Linstow, 1877) Sudarikov, 1956 (Trematoda, Cyathocotylidae). Bulletin de 1'Académie polonaise des sciences: Série des sciences biologiques 6 (9): 377-382.

Linowska A.A., Sobecka E. 2015. Health risks associated with freshwater fish consumption. European Journal of Nutrition and Food Safety 5 (4): 275-280. DOI: 10.9734/EJNFS/2015/17597

Mineeva O.V. 2016. Parazity obyknoviennoj ŝipovki Cobitis taenia Linnaeus, 1758 (Pisces: Cobitidae) v Saratovskom vodohranilise. [Parasites of the spiny loach Cobitis taenia Linnaeus, 1758 (Pisces: Cobitidae) from Saratov Reservoir.] Rossijskij parazitologičeskij žurnal [Russian Journal of Parasitology] 38 (4): 502-508.
Nawa Y., Hatz C., Blum J. 2005. Sushi delights and parasites: The risk of fishborne and foodborne parasitic zoonoses in Asia. Clinical Infectious Diseases 41 (9): 1297-1303. DOI: 10.1086/496920

Okulewicz J. 1984. Przywry ptaków Dolnego Śląska. II. Przywry przewodu pokarmowego nura rdzawoszyjego (Gavia stellata Pont.). [Bird trematodes of Lower Silesia. II. Intestinal trematodes of red-throated loon (Gavia stellata Pont.).] Wiadomości Parazytologiczne 30 (4): 503-519. [In Polish.]

Rząd I., Sitko J., Kavetska K., Kalisińska E., Panicz R. 2013. Digenean communities in the tufted duck [Aythya fuligula (L., 1758)] and greater scaup $[A$. marila (L., 1761)] wintering in the north-west of Poland. Journal of Helminthology 87 (2): 230-239. DOI: $10.1017 /$ S0022149X12000284

Schuster R., Wanjek C., Hering-Hagenback S. 1998. Untersuchung von Karpfenfischen (Cyprinidae) auf Metazerkarien der Familie Opisthorchiidae. Mitteilungen der Österreichischen Gesellschaft für Tropenmedizin und Parasitologie 20: 123-127.

Seo M., Guk S.-M., Chai J.-Y., Sim S., Sohn W.-M. 2008. Holostephanus metorchis (Digenea: Cyathocotylidae) from chicks experimentally infected with metacercariae from a fish, Pseudorasbora parva, in the Republic of Korea. Korean Journal of Parasitology 46 (2): 83-86. DOI: $10.3347 / \mathrm{kjp} .2008 .46 .2 .83$

Shershnevaa A.V., Zhokhov A.E. 2013. Parasites of stone loach Barbatula barbatula (L., 1758) (Balitoridae) in small rivers of the upper and middle Volga basin. Inland Water Biology 6 (3): 236-245. DOI: 10.1134/ S1995082913030127

Skorobrekhova E.M. 2009. Encapsulation of the metacercariae of two species of trematodes in the skin and musculature of the stone cockscomb Alectrias alectrolophus (Pallas, 1814). Russian Journal of Marine Biology 35 (2): 178-182. DOI: 10.1134/ S1063074009020102

Sobecka E., Jurkiewicz E., Piasecki W. 2004. Parasite fauna of ide, Leuciscus idus (L.) in Lake Dąbie, Poland. Acta Ichthyologica et Piscatoria 34 (1): 33-42. DOI: 10.3750/AIP2004.34.1.04

Sobecka E., Piasecki W. 2011. Fish and shellfish diseases and seafood quality. Pp. 245-257. In: DaczkowskaKozon E.G., Sun Pan B. (eds.) Environmental effects on seafood availability, safety, and quality. CRC Press, Taylor and Francis Group, Boca Raton, London, New York.

Sokolov S.G. 2013. Novye dannye o parazitofaune rotana Perccottus glenii (Actinopterygii: Odontobutidae) Primorskom krae s opisaniem novogo vida mokrosporidij roda Myxidium (Myxozoa: Myxidiidae). [New data on parasite fauna of the Chinese sleeper Perccottus glenii (Actinopterygii: Odontobutidae) in Primorsky Territory with the description of a new myxozoan species from the genus Myxidium (Myxozoa: Myxidiidae). Parazitologiâ 47 (1): 77-99.

Sulgostowska T. 2007. Przywry układu pokarmowego ptaków (nadrodzina Diplostomoidea) $\mathrm{z}$ jezior 
mazurskich. [Intestinal digeneans of birds (superfamily Diplostomoidea) of the Masurian lakes]. Wiadomości Parazytologiczne 53 (2): 117-128.

Sulgostowska T., Czaplińska D. 1987. Katalog Fauny Pasożytniczej Polski. IV. Pasożyty ptaków, zeszyt 1. Pierwotniaki i przywry. [Catalogue of Polish parasite fauna. IV. Parasites of birds, part 1. Protistans and digenean flukes.] PWN, Warszawa-Wrocław, Poland.

Wierzbicka J., Einszporn-Orecka T. 1972. Metacerkariae Paracoenogonimus ovatus przyczyną wychudzenia leszczy. [Metacercariae of Paracoenogonimus ovatus as a causative agent of emaciation of common bream.] Gospodarka Rybna 1972 (8): 4-7. [In Polish.]

Wiśniewski B., Wolski T. 2005 Changes in Dąbie Lake bathymetry in the period 1962-1996. Limnological Review 5: 255-262.

Zhokhov A.E., Pugacheva M.N., Molodozhnikova N.M. 2017. Parasites of the invasive goby Proterorhinus semilunaris (Pisces: Gobiidae) in Rybinsk Reservoir and checklist of the parasites of gobiids (genus Proterorhinus) in Eurasia. Russian Journal of Biological Invasions 8 (1): 18-33. DOI: 10.1134/ S2075111717010155

Zhytova E.P., Romanchuk L.D., Guralska S.V., Andreieva O.Yu., Shvets M.V. 2019. Circulation pathways of trematodes of freshwater gastropod mollusks in forest biocenoses of the Ukrainian Polissia. Vestnik Zoologii 53 (1): 13-22. DOI: 10.2478/vzoo2019-0002

Zolovs M., Kanto J., Jakubāne I. 2018. The distribution of digenean metacercariae within bream (Abramis brama) gill apparatus: preferences, co-occurrence and interactions of parasites. Journal of Helminthology 92 (3): 332-342. DOI: 10.1017/S0022149X1700044X

Received: 20 September 2019

Accepted: 10 December 2019 Published electronically: 15 December 2019 